\title{
Green Synthesis and Comparison of Biological Properties of Ag-NPs as a Metal Nanoparticle with ZnO-NPs as a Metal Oxide Nanoparticle and their Applications
}

Hoda Shabestarian

Masoud Homayouni Tabrizi ( $\nabla$ mhomayouni6@gmail.com )

https://orcid.org/0000-0002-5078-9973

Monireh Movahedi

Ali Neamati

Fariba Sharifnia

\section{Research Article}

Keywords: Zinc-oxide nanoparticle, Silver nanoparticle, Green-synthesize, Antioxidant, Antiangiogenesis

Posted Date: February 7th, 2022

DOI: https://doi.org/10.21203/rs.3.rs-1324734/v1

License: (c) (i) This work is licensed under a Creative Commons Attribution 4.0 International License.

Read Full License 


\section{Abstract}

\section{Aim}

The aim of study was synthesized both silver- and zinc-oxide nanoparticles utilizing the Peganum harmala smoke extract (PHSE) bio-platform to evaluate their cytotoxicity on different types of human cancer cell lines and study their antioxidant, and antiangiogenic potentials.

\section{Material and Methods}

The Ag and $\mathrm{ZnO}$ nanoparticles were produced utilizing the green-synthesize method applying PHSE bioplatform. After characterization by XRD, DLS, FESEM, and FTIR methods, MTT assay was used for evaluation toxicity of nanoparticles. ABTS, DPPH, FRAP and ROS for antioxidant capacity, CAM and qPCR for antiangiogenesis effects of nanoparticle's were used

\section{Results}

Ag-NPs (82.42 nm) and ZnO-NPs (163.05 nm) were inhibited prostate, ovarian and liver malignant cells. Inhibition $\mathrm{ABTS}^{\circ+}$ and $\mathrm{DPPH}^{++}$and increasing the rate of intracellular ROS exhibited the anti and prooxidant capacity of Ag and ZnO-NPs out and inside of malignant cells. Also, their anti-angiogenesis impact was verified by significant dose-dependent VEGF and VEGFR down-regulation and the decreased blood vessels in the chicks' chorioallantoic membrane (CAM).

\section{Conclusion}

The antioxidant, cytotoxicity and anti-angiogenesis effects of Ag and ZnO-NPs synthesized from Pecan smoke extract make it possible to use these nanoparticles in cancer chemotherapy.

\section{Introduction}

Nanotechnology is one of the emerging branches of science with wide application in the field of biomedicine[1]. Size-dependent quantum effects alter the physicochemical and biological properties of nanomaterial relative to their bulk counterparts. The small size of nanoparticles and the presence of a higher percentage of atoms on their surface make it possible to interact with biomolecules both on the surface and inside the cells of the body and can leading to achieve methods for diagnosing and treating cancer [2].

Nanotechnology has taken an important step in improving the quality of anti-cancer drugs by producing nano drugs and targeting tumor cells [3]. One of the important fields of study in biomedical sciences is the evaluation of pharmacological properties of nanomaterial [4]. Silver and ZnO-NPs have recently 
attracted considerable attention due to their beneficial and potential effects on human health. The use of plant extracts and natural products as reducing and stabilizing agents in the synthesis of these nanoparticles (green synthesis) can increase clinical efficiency and reduce the effects of toxicity and inefficiency of nanoparticles synthesized by chemical and physical methods [5]. In various studies, the antioxidant [6, 7], anti-cancer [8, 9], antimicrobial [10,11] and anti-angiogenesis $[12,13]$ activities of these nanoparticles have been investigated and confirmed.

NPs can lead to cell death by increasing the intracellular reactive oxygen species (ROS), followed by increased oxidative stress and inflammatory products such as cytokines $[14,15]$. ROS are produced as byproducts of oxygen metabolism in the body and play several physiological roles, such as cellular signaling. However, some factors such as environmental stressors help increase ROS production and subsequently cause an imbalance in production and its elimination by the antioxidant system. Antioxidants play an important role in the body's defense against the damaging effects of free radicals and ROS. An imbalance between antioxidants and ROS causes oxidative stress and subsequent cell damage [16]. Although an increase in ROS in healthy cells can cause carcinogenesis, however, the increase in ROS and subsequently damage to biological macromolecules and the initiation of apoptosis is one of the most important mechanisms for the removal of cancer cells in chemotherapy [17]. Despite the inhibitory effect of $\mathrm{ZnO}$ and $\mathrm{Ag}$ nanoparticles on free radicals in vitro [6, 7], their role in the production of oxidative stress following the increase in ROS in cancer cells has been shown in various studies [18, 19]. Cancer cells have a negative charge on their surface due to the high percentage of anionic phospholipids and certain groups of charged proteins and carbohydrates on their surface, and this feature can cause electrostatic interaction of nanoparticles with a positive surface charge to cancer cells as target cells [20,21]. Exposure of cancer cells to nanoparticles activates cellular defense mechanisms to minimize damage, and if the stimulation of ROS production within the cell by nanoparticles is greater than the cell antioxidant defense capacity, the cells undergo apoptosis [14,15]. Other effective mechanisms of nanoparticles in inhibiting cancer cells include inhibition of angiogenesis and their anticancer effects. Studies have shown that cells in tumor tissue create new blood vessels, by secreting stimulatory factors. Therefore, the initial growth of the tumor and its continued growth depends on adequate blood supply to the tumor tissue, and inhibition of blood flow can prevent further tumor growth [22]. Various studies have confirmed the inhibitory effect of silver [13] and ZnO-NPs [12] on angiogenesis. However, some studies have reported the pro-angiogenesis effects of ZnO-NPs [23].

In current survey, for the first time, Pecan smoke extract was used to synthesize $\mathrm{ZnO}$ and Ag-NPs by green way. After characterizing and confirming the synthesis of nanoparticles, their antioxidant, cytotoxic and anti-angiogenesis effects were investigated and compared.

\section{Material And Methods \\ 2.1. Materials}


ABTS, DPPH, MTT, ferric tripyridyl triazine (Fe ${ }^{3+}$ TPTZ), Dimethyl sulfoxide (DMSO), Zinc acetate, silver nitrate were purchased from Merck Co. The human cancer cell lines including PC3, A2780, HepG2, and HFF were purchased from ferdowsi university of Mashhad, Iran. All the materials needed for cell culture were bought from Sigma Aldrich.

\subsection{PHSE extraction}

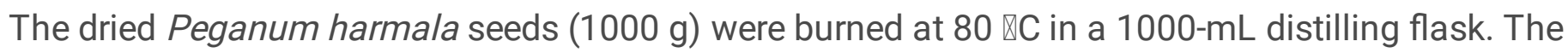
oxygen gas was injected 1 puff per 5 minutes during burning. Then, the smoke components were collected by cooling and distilling by a condenser tube. N-Hexane was used as the collector solvent then, the Peganum harmala smoke extract (PHSE) was dried.

\subsection{Zn-oxide nanoparticles synthesis}

Zinc acetate were added at $9 \mathrm{gr}$ concentration in $20 \mathrm{ml}$ distilled water (DW) and mixed for $1 \mathrm{~h}$ at $40^{\circ} \mathrm{C}$. After adding the PHSE $(20 \mathrm{mg}), 1 \mathrm{M} \mathrm{NaOH}$ solution was added drop wiseto the mixture. In order to form a white precipitate of nanoparticles, the resulting mixture was placed on the heater for 2 to 3 hours. Sediment (ZnO-NPs) was collected by centrifugation $(8000 \mathrm{rpm}, 20 \mathrm{~min})$ and then dried at $80^{\circ} \mathrm{C}$ for 2 hours.

\subsection{Ag-NPs synthesis}

In order to synthesize silver nanoparticles, $0.85 \mathrm{~g}$ of silver nitrate was added to $500 \mathrm{ml}$ of DW and after adding $20 \mathrm{mg}$ of the PHSE, it was placed on the stirrer $\left(3 \mathrm{~h}\right.$ at $\left.37^{\circ} \mathrm{C}\right)$. The NPs were centrifuged and dried at $80^{\circ} \mathrm{C}$ for $2[24,25]$.

\subsection{Identification of $\mathrm{Ag}$ and $\mathrm{ZnO}-\mathrm{NPs}$}

The size and dispersion index (PSI) of NPs were evaluated by DLS method and then XRD assay was used to evaluate the crystal structure and phase of pure Ag and ZnO-NPs. The FTIR spectroscopy was applied to verify the NPs' formation, features, and interactions [26]. The size and morphology of NPs were evaluated by FESEM. For this purpose, a drop of nanoparticles $(1 \mathrm{mg} / 10 \mathrm{~mL}$ distilled water) was sprayed on a special grade and after drying and coating, it was examined microscopically.

\subsection{Cell Culture}

The PC3, A2780, and HepG2 as cancer cells and HFF as normal cells were seeded at the $8 \times 10^{4}$ cells $/ \mathrm{cm}^{2}$ density in special cell culture media (RPMI or DMEM) at $37 \mathbb{}$ C. The media was supplemented by FBS, streptomycin, and penicillin in the required proportion.

\subsection{MTT assay}

For this purpose, $5 \times 10^{3}$ cells in each well of 96-well plates were cultured for $24 \mathrm{~h}$ and after that, the cells were exposed with serial doses of NPs. After $48 \mathrm{~h}$ the old culture media of each treating group was refreshed with a fresh media supplemented with MTT $(0.5 \mathrm{mg} / \mathrm{mL})$. The cells were incubated $(3 \mathrm{~h}$ at $37 \llbracket \mathrm{C}$ ) and next, the MTT solution was replace with $100 \mu \mathrm{l}$ of DMSO. The OD of sample was recorded at 
$570 \mathrm{~nm}$ and used for calculating the viability of the cells: Cell viability $(\%)=(\mathrm{OD}$ sample/OD control $) \times$ 100.

\subsection{Antioxidant assay \\ 2.8.1. ABTS assay}

The antioxidant potential of $\mathrm{Ag}$ and $\mathrm{ZnO}$ nanoparticles was assessed by determining their ability to reducing the ABTS free radicals [27]. Briefly, ABTS solution was made by adding potassium persulfate and ABTS in a proportion of $2.45 \mathrm{mM}: 7 \mathrm{mM}$ in distilled water (1:1). The solution was incubated for $16 \mathrm{~h}$ at room temperature (RT) and diluted with DW. Absorbance of the diluted solution was recorded at 0.700 in $734 \mathrm{~nm}$ wavelength. Then, the diluted solution of ABTS was mixed with a range of nanoparticles' concentrations with equal volume and incubated for $1 \mathrm{~h}$ in dark conditions at RT; finally, the absorbance of ABTS was read at $734 \mathrm{~nm}$.

\subsubsection{DPPH assay}

For this, an ethanolic solution of DPPH $(1 \mathrm{mg} / 16 \mathrm{ml})$ was made and mixed with a range of nanoparticles' different concentrations in equal volume. Then, the solution was incubated for $30 \mathrm{~min}$ in dark at room temperature and, the samples absorbance was read at $517 \mathrm{~nm}$. The antioxidant activity of NPs was measured by using the following equation:

\section{Antioxidant activity $=\frac{\text { Sample } O D-\text { Control } O D}{\text { Control } O D} \times 100$}

\subsubsection{FRAP assay}

The antioxidant potential of $\mathrm{Ag}$ and $\mathrm{ZnO}$ nanoparticles was studied by detecting their reductive potential for producing ferrous from ferric ions. According to the Benzie and Strain protocol [28], the solution called FRAP was prepared by mixing tripyridyltriazine (TPTZ), $\mathrm{HCL}$, acetate buffer, and $\mathrm{FeCl}_{3} \cdot 6 \mathrm{H}_{2} \mathrm{O}$ in a proportion of $10 \mathrm{ml}: 40 \mathrm{mM}: 300 \mathrm{mM}: 20 \mathrm{mM}$ at $37^{\circ}$. Finally, different doses of nanoparticles $(1,2,3,4,5$, and $6 \mathrm{mg} / \mathrm{mL}$ ) were mixed with the FRAP solution in a ratio of 20:280 $\mu \mathrm{l}$. The standard curve was prepared regarding the $\mathrm{FeSO}_{4}$ absorbance of the several standard doses at $593 \mathrm{~nm}$ [29]. Then, after 30 min incubation in FRAP solution, the absorbance of both ZnO- and Ag-NPs was recorded. The FRAP values were expressed as the produced ferrous ions $(\mathrm{mg})$ for each concentration of nanoparticles $(\mathrm{mg})$. All the measurements were carried out in triplicate manner.

\subsubsection{ROS assay}

ROS is naturally produced in cells as a byproduct of oxygen metabolism. Increasing the amount of ROS due to environmental pressures causes damage to macromolecules and cellular structures and causes oxidative stress. In this study, due to the high sensitivity of A2780 cells to both nanoparticles, this cell line was used to evaluate the amount of intracellular ROS. For this, cells were cultured in 96-well plates and 
$48 \mathrm{~h}$ after treatment with various doses of NPs were prepared according to the protocol of the ROS kit, and finally the fluorescence intensity was measured (excitation 480-500 nm and emission $510-550 \mathrm{~nm}$ ) [30].

\subsection{Anti-angiogenesis activity of Ag and ZnO-NPs 2.9.1. CAM assay}

The anti-angiogenesis potential of NPs was analyzed by performing the CAM assay. Briefly, 64 fertilized

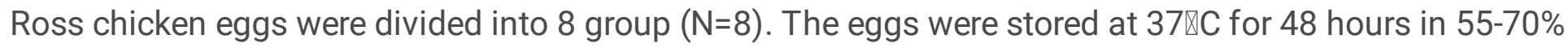
humidity. Then, a $1-\mathrm{cm}^{2}$ window was cut on the shell of eggs and sealed by sterilized paraffin. Samples were treated with various doses of NPs on the eighth day as following treatment plan:

- Control group: no treatment

- Lab control: treating with PBS (0.1 M)

- Experimental groups: treating with different doses of both NPs

Finally, the eggs were resealed and incubated for $72 \mathrm{~h}$. The number and length of the CAM blood vessels were measured utilizing the stereomicroscopic photos and image $\mathrm{J}$ software. Calipers and scales were used to measure the height and weight of the fetuses [31].

\subsubsection{Gene expression profile}

The antiangiogenic activity of both NPs was measured on the chorioallantoic membrane tissue of the treated eggs. For this purpose, chorioallantoic membranes were separated from the eggs and pulverized in separate groups with liquid nitrogen. Then, using the bioteck kit, their total RNA was extracted and the amount of RNA in each group was evaluated by Nano drop method. Then a certain volume of RNA was used to synthesize cDNA. The resulting CDNA with sybergreen, specific primer and deionized distilled water to evaluate the expression of VEGF and VEGFR as angiogenesis genes was examined by qPCR device (Bio-Rad CFX96).

\subsection{Statistical study}

For the cam method, image $\mathrm{J}$ software was used and then the data obtained from different experiments were analyzed with SPSS software version 21. One way ANOVA and LSD test was used to evaluate the significance level of the results. The less than $0.05 p$-values were assigned as the significant levels.

\section{Findings}

\subsection{Identification of Ag-NPs}

The Z-average and PDI values of Ag-NPs were estimated $82.42 \mathrm{~nm}$ and 0.25 , respectively, which make Zaverage as a reliable size index regarding Stetefeld's theory (Fig. 1A). The theory demonstrates that less than $0.7 \mathrm{PDI}$ values refer to the mono-distribution condition [32]. Also, the XRD algorithms show the 
crystal features Ag-NPs (Fig. 1B). The individual pecks of Ag-NPs crystals are observable at 32 and $542 \theta-$ degrees. FE-SEM micrographs of Ag-NPs indicate its pseudo spherical morphology, support the DLS data and approve their estimated D mean number values (Fig. 1C). FTIR spectrum of Ag-NPs expressed visible bands at $3314.84(\mathrm{O}-\mathrm{H}$ and $\mathrm{N}-\mathrm{H}$ stretching), 2923.14 and 2847.67 (C-H stretching), 1691.26 and 1596.60 ( $\mathrm{N}-\mathrm{H}$ stretching), 1454.26 and 1357.90 (C-H stretching), 1245.86 (C-C(=0)-O stretching), 1156.0 (asymmetric stretching of the C-O-C), 1066.18 (C-O stretching), and The peak at $602.96 \mathrm{~cm}^{-1}$ is attributed to the bonding of oxygen from the $\mathrm{O}-\mathrm{H}$ groups [33]. The FTIR data (Fig. 1D) indicate that the biological molecules could possibly be involved for synthesis and stabilization of Ag-NPs.

\subsection{Characterization of ZnO-NPs}

The DLS data exhibited the formation of ZnO-NPs with a size of $163.05 \mathrm{~nm}$ and PDI of 0.25 . Since colloidal particles with dispersion index of 0-0.7 are introduced as particles with uniform dispersion, so ZnO-NPs can be considered as monodisperse particles (Fig. 1A). FESEM results confirm the presence of spherical particles with a rough appearance and size of about $100 \mathrm{~nm}$, which is consistent with the data from DLS (Fig. 2B). The XRD algorithm of ZnO-NPs (the specific picks for $2 \theta$ values in the range of 30 to 40 degrees) (Figure $2 \mathrm{C}$ ) verified their synthesis. The chemical features of ZnO-NPs were defined by two specific lowest and highest wavenumbers at $435.18 \mathrm{~cm}^{-1}$ and $3436.97 \mathrm{~cm}^{-1}$, respectively (Fig. 2D). The sharp peak at $435.18 \mathrm{~cm}^{-1}$ is the corresponding to the $\mathrm{Zn}-0$ stretching bond. The absorption peaks at the range of 1700 to $600 \mathrm{~cm}^{-1}$ attributed to $\mathrm{C}=\mathrm{O}, \mathrm{C}-\mathrm{O}$ and $\mathrm{C}-\mathrm{H}$ vibrations respectively. Other peaks are due to the hydroxyl stretching vibrations and bending modes of the adsorbed water [34].

\subsection{The cytotoxicity of Ag-NPs}

The effect of concentration-dependent toxicity of silver nanoparticles against cancer cell lines compared to normal is shown in Fig. 3. As shown in the diagram (Fig. 3A), prostate cancer cells show the highest resistance to treatment, while ovarian and liver cancer cells are highest sensitive to treatment. Ag-NPs reduced only HepG2 and A2780 cancer cells in lower than its $\mathrm{IC}_{50}$ doses for normal HFF cells (Fig. 3B). Therefore, the safe toxic doses (STD) of Ag-NPs are defined at lower the $19.23 \mu \mathrm{g} / \mathrm{ml}$.

\subsection{The cytotoxicity of ZnO-NPs}

The results MTT assay showed that ZnO-NPs are able to inhibit all three cancer lines in dose-dependent way (Fig. 4A). No inhibitory effect against normal cells was reported at the concentrations studied. Examination and comparison of $\mathrm{IC}_{50}$ showed that nanoparticles inhibited A2780, HepG2 and PC3 cells with moderate concentrations of $11.65,47.36$ and $49.96 \mu \mathrm{g} / \mathrm{mL}$, respectively (Fig. 4B). Thus, A2780 cell showed the highest sensitivity to ZnO-NPs treatment compared to other cells.

\subsection{Antioxidant capacity of Ag-NPs}

Figure $5 \mathrm{~A}$ demonstrations the potential of Ag-NPs to reduce iron ions compared to Feso4 as a standard antioxidant. According to the Fig, the FRAP value increases with increasing concentration of Ag-NPs and its highest value (0.14) is observed at a concentration of $4 \mathrm{mg} / \mathrm{mL}$ Ag-NPs. Therefore, it can be said that nanoparticles at a concentration of $4 \mathrm{mg} / \mathrm{mL} 0.1$ Feso 4 have the ability to reduce iron ions. The 
concentration-dependent inhibitory effects of Ag-NPs against ABTS and DPPH free radicals are shown in Fig. 5B. As can be seen, nanoparticles are able to inhibit $50 \%$ of ABTS free radicals at a concentration of about $200 \mu \mathrm{g} / \mathrm{mL}$, while the median concentration for inhibiting DPPH free radicals is about $707.3 \mu \mathrm{g} /$ $\mathrm{mL}$. Therefore, the results show higher inhibitory effects of nanoparticles on ABTS free radicals compared to DPPH. Evaluation of changes in intracellular ROS in Ag-NPs treatment was measured by adsorption method (5C). The results showed a significant increase in the amount of intracellular ROS in the treated cells with a concentration of $2 \mathrm{mg} / \mathrm{mL}$. As the concentration of the treatment increases, the amount of intracellular ROS increases dramatically, this confirms the role of Ag-NPs in inducing cell death by increasing intracellular ROS and causing oxidative stress damage [30].

\subsection{Antioxidant capacity of Zno-NPs}

The reducing power of iron ions in the presence of ZnO-NPs compared to Feso4 was evaluated by FRAP method. The results showed that nanoparticles at the highest concentration are able to inhibit iron ions with a frap value of about 0.1 (Fig. 6A). The inhibitory effect of ZnO-NPs on ABTS and DPPH free radicals was evaluated to evaluate the antioxidant power of ZnO-NPs. As shown (Fig. 6B), increasing the concentration of ZnO-NPs increases the inhibition rate and the highest percentage of inhibition for ABTS free radicals is reported at a concentration of $2 \mathrm{mg} / \mathrm{mL} \mathrm{ZnO-NPs}$ of about $4 \%$. While at similar concentrations, about $34.25 \%$ of DPPH free radicals were inhibited. These results confirm the moderate inhibitory potency of ZnO-NPs against DPPH free radicals. One of the most important features of anticancer compounds is their ability to induce intracellular ROS, followed by cell damage and induction of cell death. In this study, intracellular ROS changes were evaluated in cells treated with different concentrations of ZnO-NPs. The results, showed a significant increase in ROS in treated cells with concentration of 8,16 and $32 \mu \mathrm{g} / \mathrm{mL}$ (Fig. 6C).

\subsection{Anti-angiogenesis potential of Ag-NPs}

Figure 7A shows the images of the treated area in the experimental groups compared to the control. As can be seen, the images clearly show the reduction of blood vessels in the treated groups with 250 and $500 \mu \mathrm{g} / \mathrm{mL}$ of Ag-NPs. Examination of the mean number of blood vessels in control laboratory control and samples treated with a concentration of $125 \mu \mathrm{g} / \mathrm{mL}$ Ag-NPs not show a statistically significant difference $(P>0.05)$. However, with increasing the concentration to $250\left({ }^{\star} P<0.05\right)$ and $500 \mu \mathrm{g} / \mathrm{ml}$ $(\star \star \star P<0.001)$, a significant decrease in the number of blood vessels is observed. Significant reduction in blood vessel length was also observed only in treated samples with concentrations of $250(* * P<0.01)$ and $500 \mu \mathrm{g} / \mathrm{mL}$ ( $* \star * P<0.001)$. Examination of fetal height and weight in experimental groups compared to control shows that only in samples treated with a concentration of $500 \mu \mathrm{g} / \mathrm{mL}$ there is a significant reduction $\left({ }^{*} \mathrm{P}<0.05\right)($ Fig. $7 \mathrm{~B})$. Examination of alterations in the expression of angiogenesis-related genes in Ag-NPs-treated samples showed that the VEGFR gene was significantly reducing in all concentrations studied, while the expression of the VEGF gene at both concentrations of 125 and $250 \mu \mathrm{g} / \mathrm{mL}$ is approximately constant and similar to the control group, while in the samples treated with a concentration of $500 \mu \mathrm{g} / \mathrm{mL}$, its expression was significantly reduced (Fig. 7C).

\subsection{Anti-angiogenesis properties of Zno-NPs}


Microscopic changes of vessels in nanoparticle-treated samples compared to the control are shown in Fig. 8A. As can be seen, the amount of blood vessels in the experimental groups is almost similar to the control sample. To further evaluate the effect of nanoparticles on angiogenesis, mean length and number of blood vessels were evaluated with Imag $\mathrm{J}$ software and the results exhibited an increase in the average number of blood vessels in the two treated groups $500\left({ }^{*} P<0.05\right)$ and $1000 \mu \mathrm{g} / \mathrm{mL}(* * P<0.01)$. While the average length of blood vessels showed an increase only in $1000 \mu \mathrm{g} / \mathrm{mL}\left({ }^{*} \mathrm{P}<0.01\right)$ treated group. An increase in the mean length $\left({ }^{*} P<0.01\right)$ and weight $\left({ }^{*} P<0.05\right)$ of the embryos during the increase in vascular factors was observed only in samples treated with $1000 \mu \mathrm{g} / \mathrm{mL}$ (Fig. 8B). In order to evaluate the NPs effect on angiogenesis at the molecular level, the expression of VEGF and VEGFR genes was evaluated by QPCR method. As can be seen, at two concentrations of 250 and $500 \mu \mathrm{g} / \mathrm{mL}$, a significant decrease in the expression of genes associated with angiogenesis is observed, but with increasing the concentration of treatment to $1000 \mu \mathrm{g} / \mathrm{mL}$, the expression of genes increases significantly (Fig. 8C). Considering the alteration in the expression of angiogenesis-related genes and the results of CAM test, it can be said that the effect of ZnO-NPs on angiogenesis was dose-dependent. In such a way that at low concentrations at the molecular level, it inhibits angiogenesis and by increasing the concentration, its effect on angiogenesis is reversed. Therefore, in order to use these nanoparticles in studies related to cancer treatment, it is important to pay attention to the concentration used.

\section{Discussion}

The genotype complexity and poor prognosis of cancer are considered as the main barriers in its treatment. The use of nanotechnology as a practical field to develop effective methods in the diagnosis and treatment of cancer has been considered by many researchers today [35]. Metal and metal oxides NPs such as Ag and ZnO-NPs play a prominent role in biomedical applications [36]. In current study, Pecan smoke extract (PHSE) was used as a biological platform for the green synthesis of $\mathrm{ZnO}$ and AgNPs, and then the biological effects of nanoparticles were investigated and compared.

The use of biological systems such as plant extracts and metabolites as reducing and stabilizing agents for the fabrication of NPs is called the green synthesis method, which has been successfully used in cancer treatment approaches and is an effective step in eliminating the disadvantages of physical and chemical methods [37].

In this study, smoke from burning Peganum Harmala seeds was used to green synthesize of silver (ps: $25.99 \mathrm{~nm}$ and PDI: 0.25) and zinc oxide (ps: $55.72 \mathrm{~nm}$ and PDI: 0.25) nanoparticles. Harmala is a native plant of Iran and belongs to the Zygophyllaceae family [38, 39]. In the roots and seeds of this plant, alkaloid compounds, beta-carbolines such as harmin, Harman, quinazoline and etc. are found [40,41] and its anti-cancer, antimicrobial, anti-inflammatory and antioxidant effects have been reported in previous studies [42]. Due to the growing burden of cancer worldwide, different types of metal NPs have been fabricated through the green approach. For example, Zinc oxide-nanoparticles have been fabricated by various types of bio-platforms such as Laurus nobilis [43], Deverra tortuousa [44], Garcinia mangostana fruit [45], and Cucumis melo inodorus rough shell extracts [46]. Also, there are several types 
of plant extracts that have been utilized for synthesizing Ag-NPs including Amphipterygium adstringens [47], Centella Asiatica [48], and Ficus benghalensis prop root extracts [49]. In a study in 2015, Ag-NPs with a size of 5 to $25 \mathrm{~nm}$ from the aqueous extract of Caulerparacemosa were prepared by green method [50].. In another study, Ag-NPs were green synthesized using the sumac aqueous extract with an average size of $35 \mathrm{~nm}$ [51] which is comparable to the Ag-NPs synthesized in the present study.

Similar to the present study, in a study conducted in 2021, globular nanoparticles with $55 \mathrm{~nm}$ were fabricated by the green method. In this study, Arthrospira platensis was used as a reducing agent for the formation of NPs [52].

In this study, the toxicity of Ag-NPs and ZnO-NPs against three cancer cell lines was compared with HFF cells. The most sensitive and resistant cell lines to treatment with Ag-NPs were HepG2 and PC3 with $\mathrm{IC}_{50}$ about1.95 and above of $40 \mu \mathrm{g} / \mathrm{mL}$, respectively, while in the treatment with ZnO-NPs the highest and lowest resistance to treatment in HFF and A2780 cells with $\mathrm{IC}_{50}$ higher than $62 \mu \mathrm{g} / \mathrm{mL}$ and $11.65 \mu \mathrm{g} / \mathrm{mL}$ (respectively) was observed. Since ZnO-NPs did not show any toxic effect on normal cells at the studied concentrations, it can be said that ZnO-NPs are safer compared to Ag-NPs. Many studies similar to our study have shown the toxicity of various NPs including Ag-NPs and ZnO-NPs on cancer cells.

A study in 2018 showed higher cytotoxic effects of Ag-NPs synthesized from Artemisia tournefortiana extract against HT-29 $\left(\mathrm{IC}_{50}=40.71 \mathrm{mg} / \mathrm{mL}\right)$ compared to the HEK293 $\left(\mathrm{IC}_{50}=61.38 \mathrm{mg} / \mathrm{mL}\right)$ as a normal cells [53]. In another study was reported the strongly cytotoxic effects of Ag-NPs synthesized by aqueous extract of Rubia tinctorum against HepG-2 cells $\left(\mathrm{IC}_{50}: 6 \mu \mathrm{g} / \mathrm{mL}\right)$ compared to the HFF $\left(\mathrm{IC}_{50}: 100 \mu \mathrm{g} / \mathrm{mL}\right)$ as a normal cells [54].

In a study was conducted in 2021 on the fabricated ZnO-NPs by Swertia chirayita leaf extract revealed the toxic effects against HCT-116 and Caco-2. The nanoparticles showed a strongly cytotoxic potency against HCT-116 and Caco-2 cell lines, but less so against the normal HEK-293 cell line [55]. Also, in a study in 2019, Mahdizadeh et al. have reported the toxicity of ZnO-NPs from Cucumis melo on MCF7 (40 $\mu \mathrm{g} / \mathrm{mL})$ and Tubo $(20 \mu \mathrm{g} / \mathrm{mL})$ cells after $24 \mathrm{~h} \mathrm{[46].}$

ROS increasing, although under natural conditions causes diseases related to oxidative stress such as cancer, but in the treatment of cancer is used as one of the applied strategies in chemotherapy [17]. Studies show that increasing the amount of ROS can lead to the release of cytochrome $\mathrm{C}$ and activation of apoptotic pathway by changing the permeability of the mitochondrial membrane [56]. Our findings show the antioxidant effect of $\mathrm{ZnO}$ and Ag-NPs in vitro and its pro-oxidant effects inside the cancer cell. Our results exhibited a significant antioxidant capability for Ag-NPs for ABTS $\left(\mathrm{IC}_{50}: 150.07 \mu \mathrm{g} / \mathrm{mL}\right)$ and DPPH $\left(\mathrm{IC}_{50}: 707.33 \mu \mathrm{g} / \mathrm{mL}\right.$ ) free radicals (Fig. 5). In other words, ZnO-NPs appeared as a weak radical scavenger compared with Ag-NPs and glutathione antioxidant potential.

In 2019, Ahmadi et al reported the inhibitory effect of ZnO-NPs against ABTS and DPPH free radicals with $\mathrm{IC}_{50}$ about of 31.2 and $60 \mu \mathrm{g} / \mathrm{mL}$ [57], which shows a higher antioxidant power compared to our study. 
Similar to the present study, in a 2015 study, the inhibitory effects of Ag-NPs from Cassia roxburghii on ABTS free radicals $\left(\mathrm{IC}_{50}: 140 \mu \mathrm{g} / \mathrm{mL}\right)$ and their reducing power on iron ions (FRAP of $2.64\left(\mathrm{Mg}^{-1}\right)$ ) were investigated and confirmed[58]. Also, in a study in 2017, 23-95\% of ABTS free radical scavenging capacity and $8.8 \mathrm{Mg}^{-1}$ FRAP activities of Ag-NPs were reported [59]. The results of many studies show that NPs increase ROS production in various cancer cells [22]. Similar to the present study, in a 2020 study, the anti-proliferative and pro-oxidant effects of Ag-NPs from Beta vulgaris $L$ were demonstrated in human hepatic cancer cells (HUH7) by ROS induction[60]. Lee et al. reported the potential to stimulate ROS production in human keratinocytes treated with ZnO-NP. They showed that the mechanism of nanoparticle toxicity is related to ROS production, oxidative stress and apoptosis [61]. In another study in 2017, Bai et al. have exhibited the increasing intracellular ROS in SKOV3 treated with ZnO-NPs [62].

The results of this investigation showed the wide range of safe toxic doses of $\mathrm{ZnO}$ and Ag-NPs indicate their pro-oxidant activity and thus approve their ROS-mediated cytotoxicity [63].

Angiogenesis is one of the most important features of tumor cells that help their survival and reducing angiogenesis plays the main role in preventing the growth of cancer cells and inflammation [22]. The results of this survey confirmed the reduction of angiogenesis in the treatment with different concentrations of Ag-NPs in CAM and qPCR assay. Investigation of the effect of ZnO-NPs on angiogenesis showed that, they suppress angiogenesis by down-regulating VEGF and VEGFR gene expression at 0 to $500 \mu \mathrm{g} / \mathrm{mL}$ concentrations and act as a pro-angiogenic compound at $>500 \mu \mathrm{g} / \mathrm{mL}$ doses. In many studies consist with the present investigation, the anti-angiogenesis effects of nanoparticles have been investigated and confirmed $[64,65]$.

For example, a reduction in angiogenesis by the CAM method was reported in a 2015 study by examining the mean number and length of blood vessels in samples treated with Ag-NPs[13]. Also, the inhibitory effect of Ag-NPs on VEGF expression in the mouse matrigel plug [64] and retinal endothelial cells [66] has been reported in previous studies.

Various investgations have shown the anti and pro angiogenesis potential of ZnO-NPs. In a study in 2019, the anti-angiogenesis effects of ZnO-NPs from Hyssops officinalis $L$ were reported using the CAM assay [12]. Ahtzaz et al reported the pro-angiogenic effects of ZnO-NPs in 2017 using the CAM method [23]. In a study by Oikawa et al., The inhibitory effect of ZnO-NPs on the formation of blood vessels by reducing the expression of VEGF and VEGFR was reported [67] which is comparable to our results.

\section{Conclusion}

According to the results, Ag-NPs were exhibited stronger antioxidants capacity than ZnO-NPs, also, the higher cytotoxic effect of Ag-NPs have been showed compared to ZnO-NPs by MTT method. In addition, Ag-NPs showed significant anti-angiogenesis effects by reducing VEGF and VEGFR genes expression. Considering the survival of cancer cells and suppression of angiogenesis, higher anti-cancer activity of Ag-NPs was detected compared to ZnO-NPs. 


\section{References}

1. C. Martínez-Vieyra et al., Comparison of $\mathrm{Ag}, \mathrm{Cu}$ and $\mathrm{Zn}$ nanoparticles obtained using Aloe vera extract and gamma ionizing radiation. J. Appl. Res. Technol. 18(5), 289-314 (2020)

2. D. Raghunandan et al., Anti-cancer studies of noble metal nanoparticles synthesized using different plant extracts. Cancer Nanotechnol. 2(1), 57-65 (2011)

3. D. Banerjee, R. Harfouche, S. Sengupta, Nanotechnology-mediated targeting of tumor angiogenesis. Vascular cell. 3(1), 1-13 (2011)

4. B.N. Singh et al., Biosynthesis of stable antioxidant $\mathrm{ZnO}$ nanoparticles by Pseudomonas aeruginosa rhamnolipids. PLoS One 9(9), e106937 (2014)

5. T. Thunugunta, A.C. Reddy, L.R. DC, Green synthesis of nanoparticles: current prospectus. Nanatechnol. Reviews 4(4), 303-323 (2015)

6. R. Ananthalakshmi, S. Rajarathinam, A.M. Sadiq, Antioxidant activity of ZnO Nanoparticles synthesized using Luffa acutangula peel extract. Res. J. Pharm. Technol. 12(4), 1569-1572 (2019)

7. C. Tanase et al., Antibacterial and antioxidant potential of silver nanoparticles biosynthesized using the spruce bark extract. Nanomaterials 9(11), 1541 (2019)

8. H.I. Gomes, C.S. Martins, J.A. Prior, Silver Nanoparticles as Carriers of Anticancer Drugs for Efficient Target Treatment of Cancer Cells. Nanomaterials 11(4), 964 (2021)

9. T. Zhang et al., Anticancer effects of zinc oxide nanoparticles through altering the methylation status of histone on bladder cancer cells. Int. J. Nanomed. 15, 1457 (2020)

10. K.S. Siddiqi, A. ur Rahman, A. Husen, Properties of zinc oxide nanoparticles and their activity against microbes. Nanoscale Res. Lett. 13(1), 1-13 (2018)

11. J. Talapko et al., Antibacterial activity of silver and its application in dentistry, cardiology and dermatology. Microorganisms 8(9), 1400 (2020)

12. G.R.K.S. Mohammad et al., Green synthesis of zinc oxide nanoparticles and evaluation of antiangiogenesis, anti-inflammatory and cytotoxicity properties. J. Biosci. 44(2), 1-9 (2019)

13. R. Khandia et al., Evaluation of silver nanoparticle mediated reduction of neovascularisation (angiogenesis) in chicken model. Adv. Anim. Vet. Sci. 3(7), 372-376 (2015)

14. J.W. Rasmussen et al., Zinc oxide nanoparticles for selective destruction of tumor cells and potential for drug delivery applications. Expert Opin. Drug Deliv. 7(9), 1063-1077 (2010)

15. E.C. Wang, A.Z. Wang, Nanoparticles and their applications in cell and molecular biology. Integr. biology 6(1), 9-26 (2014)

16. G. Pizzino et al., Oxidative stress: harms and benefits for human health. Oxidative medicine and cellular longevity, 2017. 2017

17. M. Soltani et al., Incorporation of Boswellia sacra essential oil into chitosan/TPP nanoparticles towards improved therapeutic efficiency. Materials Technology, 2021: p. 1-13 
18. D.A. Saud Alarifi et al., Induction of oxidative stress, DNA damage, and apoptosis in a malignant human skin melanoma cell line after exposure to zinc oxide nanoparticles. Int. J. Nanomed. 8, 983 (2013)

19. A. Balkrishna et al., Phytoantioxidant Functionalized Nanoparticles: A Green Approach to Combat Nanoparticle-Induced Oxidative Stress. Oxidative medicine and cellular longevity, 2021. 2021

20. Z.L. Wang, Zinc oxide nanostructures: growth, properties and applications. J. Phys.: Condens. Matter 16(25), R829 (2004)

21. E.A. Meulenkamp, Synthesis and growth of ZnO nanoparticles. J. Phys. Chem. B 102(29), 55665572 (1998)

22. N.H. Ahmed et al., Role of chitosan nanoparticles as anti-angiogenic in mice bearing Ehrlich carcinoma. Oncol. Res. Rev. 1, 1-6 (2018)

23. S. Ahtzaz et al., A study on the effect of zinc oxide and zinc peroxide nanoparticles to enhance angiogenesis-pro-angiogenic grafts for tissue regeneration applications. Mater. Design 132, 409-418 (2017)

24. S. Ahmed et al., Green synthesis of silver nanoparticles using Azadirachta indica aqueous leaf extract. J. Radiation Res. Appl. Sci. 9(1), 1-7 (2016)

25. J. Santhoshkumar, S.V. Kumar, S. Rajeshkumar, Synthesis of zinc oxide nanoparticles using plant leaf extract against urinary tract infection pathogen. Resource-Efficient Technol. 3(4), 459-465 (2017)

26. V. Mishra, R. Sharma, Green synthesis of zinc oxide nanoparticles using fresh peels extract of Punica granatum and its antimicrobial activities. Int. J. Pharma Res. Health Sci. 3(3), 694-699 (2015)

27. P. Li et al., Free radical-scavenging capacity, antioxidant activity and phenolic content of Pouzolzia zeylanica. J. Serb. Chem. Soc. 76(5), 709-717 (2011)

28. I.F. Benzie, J.J. Strain, The ferric reducing ability of plasma (FRAP) as a measure of "antioxidant power": the FRAP assay. Anal. Biochem. 239(1), 70-76 (1996)

29. N.S. Rajurkar, S. Hande, Estimation of phytochemical content and antioxidant activity of some selected traditional Indian medicinal plants. Indian J. Pharm. Sci. 73(2), 146 (2011)

30. A. Thyagarajan, R.P. Sahu, Potential contributions of antioxidants to cancer therapy: immunomodulation and radiosensitization. Integr. cancer Ther. 17(2), 210-216 (2018)

31. Z. Sanaeimehr, I. Javadi, F. Namvar, Antiangiogenic and antiapoptotic effects of green-synthesized zinc oxide nanoparticles using Sargassum muticum algae extraction. Cancer Nanotechnol. 9(1), 3 (2018)

32. J. Stetefeld, S.A. McKenna, T.R. Patel, Dynamic light scattering: a practical guide and applications in biomedical sciences. Biophys. Rev. 8(4), 409-427 (2016)

33. M. Wan, W.K.A. Khalir et al., Biosynthesized silver nanoparticles by aqueous stem extract of Entada spiralis and screening of their biomedical activity. Front. Chem. 8, 620 (2020) 
34. K.S. Babu et al., Synthesis and optical characterization of porous ZnO. J. Adv. Ceram. 2(3), 260-265 (2013)

35. S. Jabeen et al., Application of green synthesized silver nanoparticles in cancer treatment-a critical review (Materials Research Express, 2021)

36. S. Murthy, P. Effiong, C.C. Fei, Metal oxide nanoparticles in biomedical applications, in Metal Oxide Powder Technologies (Elsevier, 2020), pp. 233-251

37. J. Singh et al., 'Green'synthesis of metals and their oxide nanoparticles: applications for environmental remediation. J. Nanobiotechnol. 16(1), 1-24 (2018)

38. L.B. Abbott, G.T. Bettmann, T.M. Sterling, Physiology and recovery of African rue (Peganum harmala) seedlings under water-deficit stress. Weed Sci. 56(1), 52-57 (2008)

39. S.K. Marwat, F. ur Rehman, Medicinal and pharmacological potential of harmala (Peganum harmala L.) seeds, in Nuts and Seeds in Health and Disease Prevention (Elsevier, 2011), pp. 585-599

40. M. Kartal, M. Altun, S. Kurucu, HPLC method for the analysis of harmol, harmalol, harmine and harmaline in the seeds of Peganum harmala L. J. Pharm. Biomed. Anal. 31(2), 263-269 (2003)

41. I.D. Passos, M. Mironidou-Tzouveleki, Hallucinogenic plants in the mediterranean countries, in Neuropathology of Drug Addictions and Substance Misuse (Elsevier, 2016), pp. 761-772

42. F. Lamchouri, Antitumor properties and toxicity effects of Peganum harmala L.(Zygophyllaceae). Plant Sci. Today 1(4), 192-195 (2014)

43. S. Fakhari, M. Jamzad, H. Kabiri, Fard, Green synthesis of zinc oxide nanoparticles: a comparison. Green Chem. Lett. Rev. 12(1), 19-24 (2019)

44. Y.A. Selim et al., Green Synthesis of Zinc Oxide Nanoparticles Using Aqueous Extract of Deverra tortuosa and their Cytotoxic Activities. Sci. Rep. 10(1), 1-9 (2020)

45. M. Aminuzzaman et al., Green synthesis of zinc oxide nanoparticles using aqueous extract of Garcinia mangostana fruit pericarp and their photocatalytic activity. Bull. Mater. Sci. 41(2), 50 (2018)

46. R. Mahdizadeh et al., Green synthesized-zinc oxide nanoparticles, the strong apoptosis inducer as an exclusive antitumor agent in murine breast tumor model and human breast cancer cell lines (MCF7). J. Cell. Biochem. 120(10), 17984-17993 (2019)

47. O.E. Rodríguez-Luis et al., Green synthesis of silver nanoparticles and their bactericidal and antimycotic activities against oral microbes. Journal of Nanomaterials, 2016. 2016

48. B. Rashmi et al., Facile green synthesis of silver oxide nanoparticles and their electrochemical, photocatalytic and biological studies. Inorg. Chem. Commun. 111, 107580 (2020)

49. V. Manikandan et al., Green synthesis of silver oxide nanoparticles and its antibacterial activity against dental pathogens. 3 Biotech. 7(1), 72 (2017)

50. T. Kathiraven et al., Green synthesis of silver nanoparticles using marine algae Caulerpa racemosa and their antibacterial activity against some human pathogens. Appl. Nanosci. 5(4), 499-504 (2015)

51. F. Shahryari, Z. Rabiei, S. Sadighian, Antibacterial activity of synthesized silver nanoparticles by sumac aqueous extract and silver-chitosan nanocomposite against Pseudomonas syringae pv. 
syringae. J. Plant Pathol. 102(2), 469-475 (2020)

52. E.F. El-Belely et al., Green synthesis of zinc oxide nanoparticles (ZnO-NPs) using Arthrospira platensis (Class: Cyanophyceae) and evaluation of their biomedical activities. Nanomaterials 11(1), 95 (2021)

53. R. Movagharnia, F. Baghbani-Arani, S.A. Sadat, Shandiz, Cytotoxicity effects of green synthesized silver nanoparticles on human colon cancer (HT29) cells. Feyz Journal of Kashan University of Medical Sciences, 2018. 22(1): pp. 31-38

54. S. Ghandehari, M. Homayouni Homayouni, Tabrizi, P. Ardalan, Study of antioxidant properties and toxicity of silver nanoparticles synthesized by aqueous extract of Rubia tinctorum on liver cancer cells (HepG2) compared to normal HDF cells. Sci. J. ilam Univ. Med. Sci. 26(2), 57-67 (2018)

55. S. Patnaik et al., Cytotoxic Potential of Biogenic Zinc Oxide Nanoparticles Synthesized From Swertia chirayita Leaf Extract on Colorectal Cancer Cells. Frontiers in bioengineering and biotechnology, 2021: p. 1276

56. S. Lee et al., Vibrio vulnificus VvhA induces NF-k B-dependent mitochondrial cell death via lipid raftmediated ROS production in intestinal epithelial cells. Cell Death Dis. 6(2), e1655-e1655 (2015)

57. A. Ahmadi Shadmehri et al., Assessment of antioxidant and antibacterial activities of Zinc Oxide nanoparticles, Graphene and Graphene decorated by Zinc Oxide nanoparticles. Int. J. Nano Dimension 10(4), 350-358 (2019)

58. P. Moteriya, H. Padalia, S. Chanda, Characterization, synergistic antibacterial and free radical scavenging efficacy of silver nanoparticles synthesized using Cassia roxburghii leaf extract. J. Genetic Eng. Biotechnol. 15(2), 505-513 (2017)

59. P. Moteriya, S. Chanda, Synthesis and characterization of silver nanoparticles using Caesalpinia pulcherrima flower extract and assessment of their in vitro antimicrobial, antioxidant, cytotoxic, and genotoxic activities. Artificial cells, nanomedicine, and biotechnology, 2017. 45(8): p. 1556-1567

60. M. Bin-Jumah et al., Effects of green silver nanoparticles on apoptosis and oxidative stress in normal and cancerous human hepatic cells in vitro. Int. J. Nanomed. 15, 1537 (2020)

61. S.H. Lee et al., Effects of zinc oxide nanoparticles on gene expression profile in human keratinocytes. Mol. Cell. Toxicol. 8(2), 113-118 (2012)

62. D.-P. Bai et al., Zinc oxide nanoparticles induce apoptosis and autophagy in human ovarian cancer cells. Int. J. Nanomed. 12, 6521 (2017)

63. R. Augustine et al., Investigation of angiogenesis and its mechanism using zinc oxide nanoparticleloaded electrospun tissue engineering scaffolds. RSC Adv. 4(93), 51528-51536 (2014)

64. S. Gurunathan et al., Antiangiogenic properties of silver nanoparticles. Biomaterials 30(31), 63416350 (2009)

65. T. Yang et al., Silver nanoparticles inhibit the function of hypoxia-inducible factor-1 and target genes: insight into the cytotoxicity and antiangiogenesis. Int. J. Nanomed. 11, 6679 (2016)

66. S. Sheikpranbabu et al., Silver nanoparticles inhibit VEGF-and IL-1 $\beta$-induced vascular permeability via Src dependent pathway in porcine retinal endothelial cells. J. Nanobiotechnol. 7(1), 1-12 (2009) 
67. S. Tada-Oikawa et al., Zn (II) released from zinc oxide nano/micro particles suppresses vasculogenesis in human endothelial colony-forming cells. Toxicol. Rep. 2, 692-701 (2015)

\section{Figures}
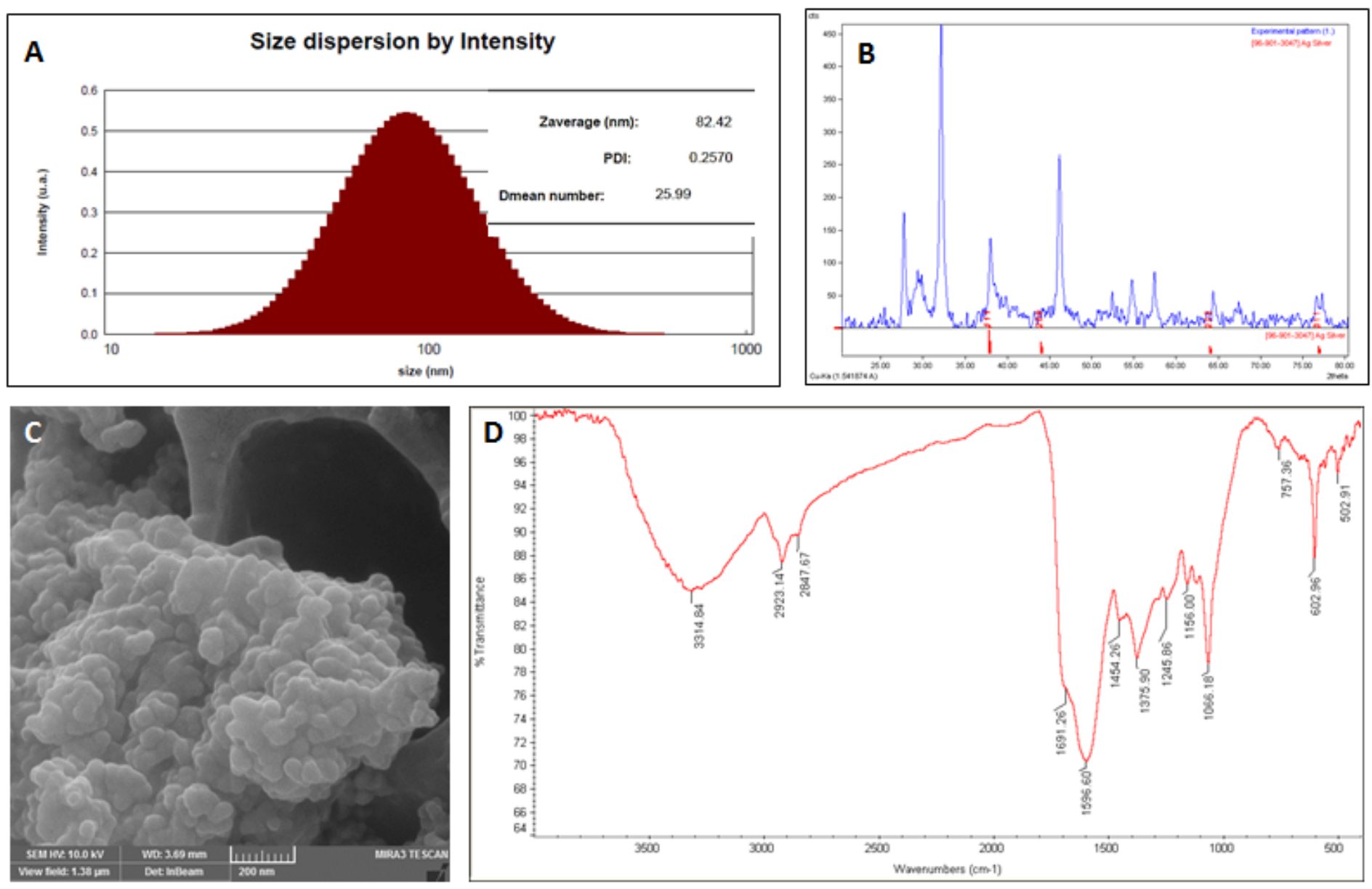

\section{Figure 1}

The Ag-NPs characterization results. (A) The Z-average and PDI indices were defined at $82.42 \mathrm{~nm}$ and 0.25 , respectively. (B) The XRD pattern of Ag-NPs. (C) The FESEM image of Ag-NPs. (D) The FTIR diagram indicating chemical characteristic of Ag-NPs. 

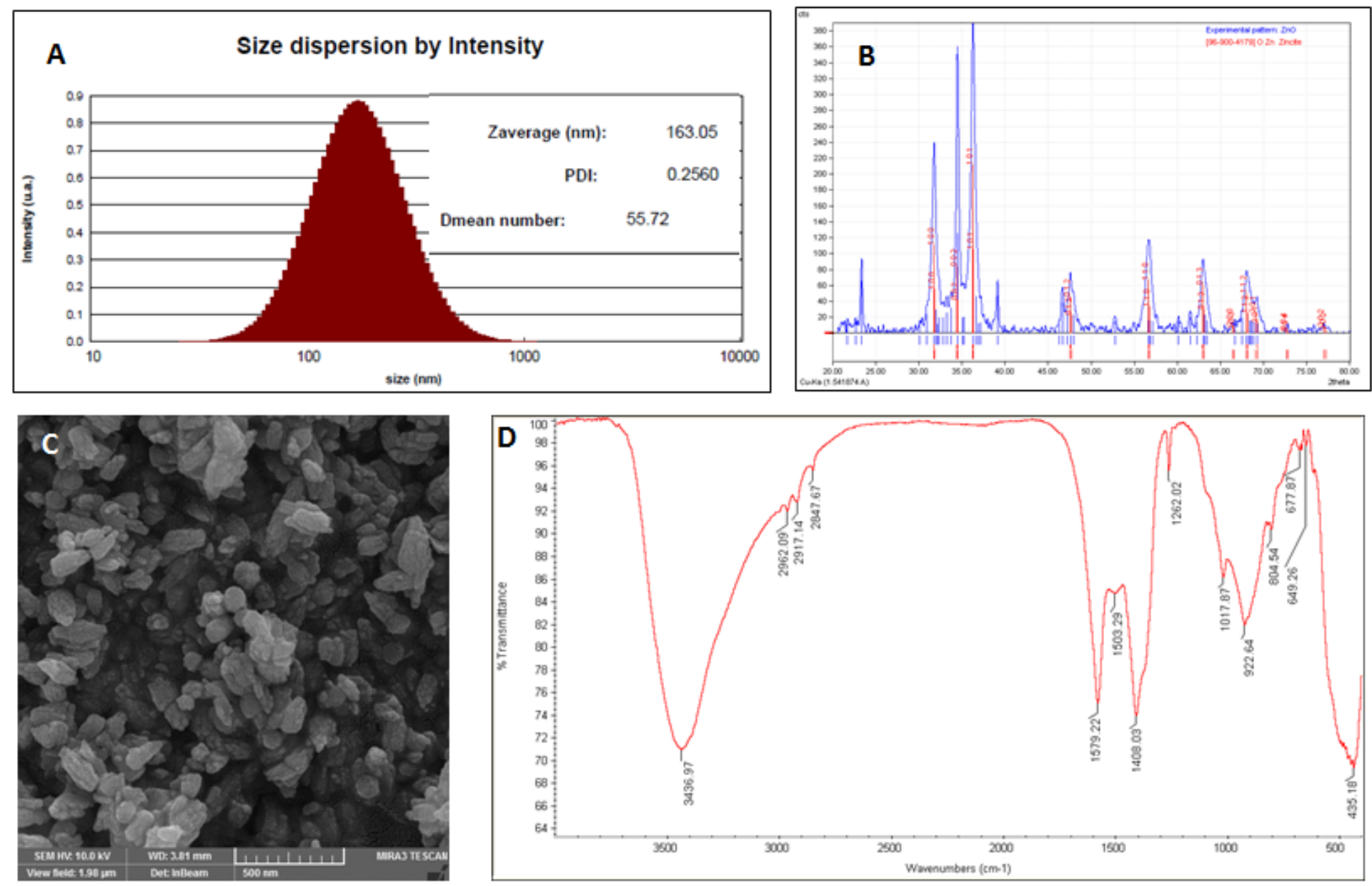

\section{Figure 2}

The ZnO-NPs characterization data. (A) The Z-average and PDI indices were defined at $163.05 \mathrm{~nm}$ and 0.25 , respectively. (B) The XRD pattern of ZnO-NPs. (C) The FESEM image of ZnO-NPs. (D) The FTIR diagram indicating chemical properties of ZnO-NPs crystal structure.

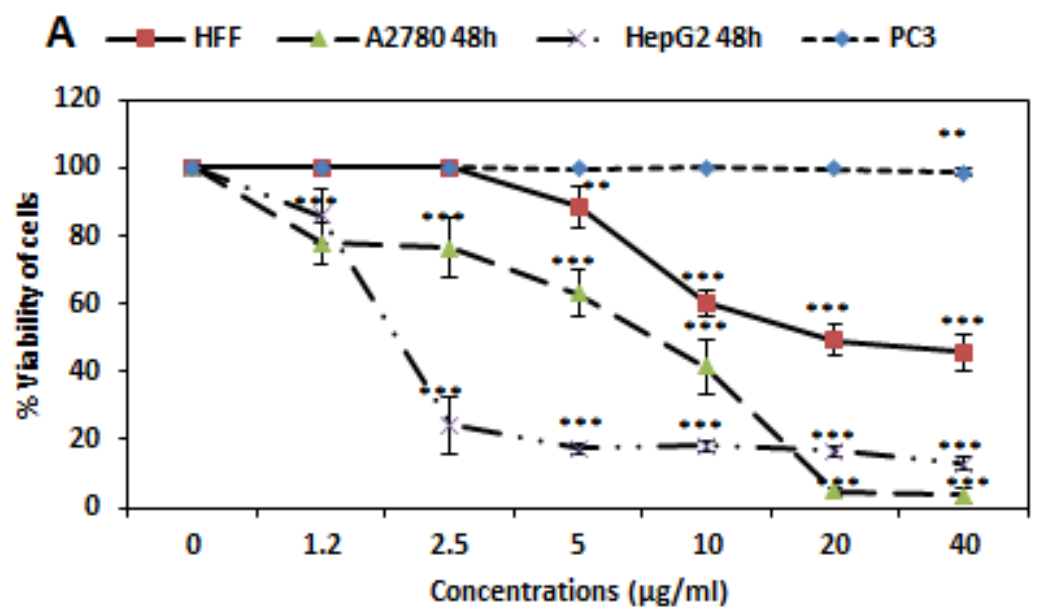

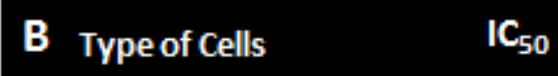

HFF

$19.23 \mu \mathrm{g} / \mathrm{ml}$

PC-3

$>40 \mu \mathrm{g} / \mathrm{ml}$

A2780

$8.01 \mu \mathrm{g} / \mathrm{ml}$

HepG2 


\section{Figure 3}

Cytotoxic effects of Ag-NPs. (A) the diagrams indicate the cancer cells' viability following to different AgNPs concentrations. $(N=3),{ }^{\star} \times P<0.01$ and ${ }^{\star *} * P<0.001$. (B) Medium concentrations $\left(I C_{50}\right)$ of Ag-NPs against different cell lines.

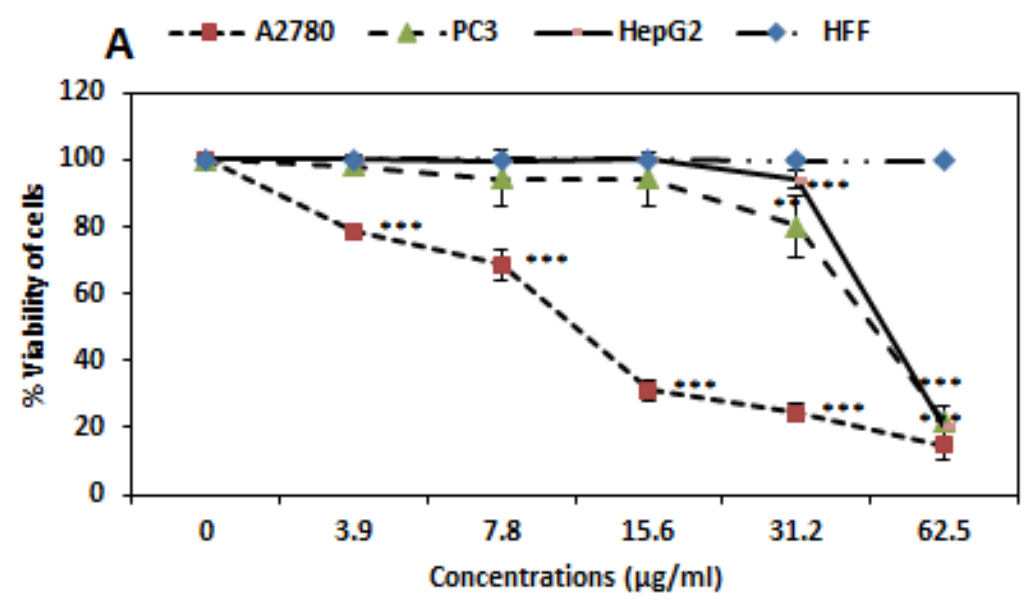

\section{B Type of Cells \\ $I_{50}$}

$>62.5 \mu \mathrm{g} / \mathrm{ml}$

HFF

$49.96 \mu \mathrm{g} / \mathrm{ml}$

HepG2

PC-3

$47.36 \mu \mathrm{g} / \mathrm{ml}$

A2780
$11.65 \mu \mathrm{g} / \mathrm{ml}$

\section{Figure 4}

The cytotoxic activity of ZnO-NPs. (A) the diagrams indicate the cancer cells' viability following to different ZnO-NPs concentrations ( $N=3)$, ${ }^{\star \star *} P<0.001$. (B) Medium concentrations $\left(I_{50}\right)$ of $Z n O-N P s$ against different cell lines. 

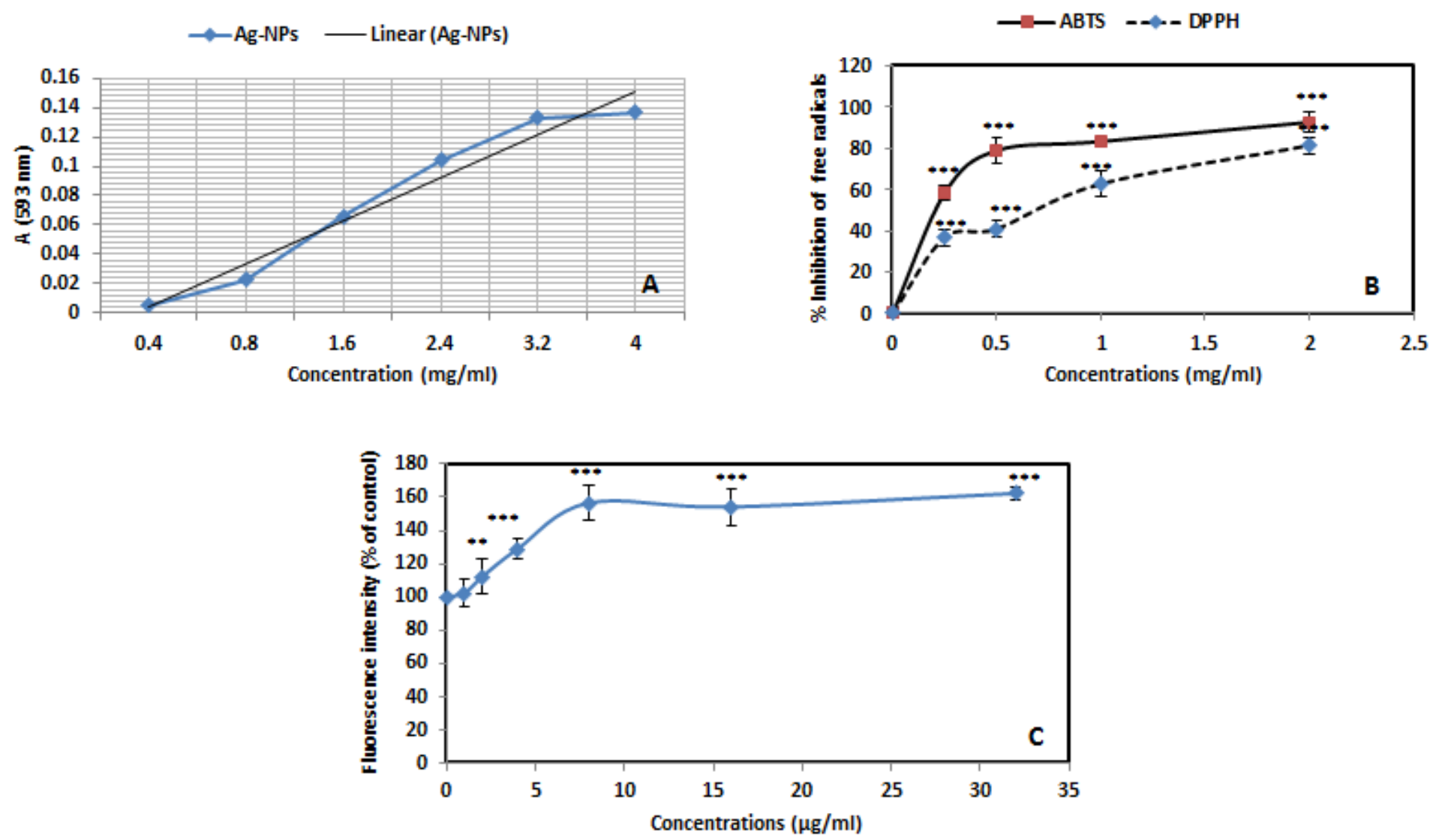

\section{Figure 5}

The Ag-NPs antioxidant activity. (A) The FRAP assay data. (B) Scavenging of ABTS and DPPH free radicals with nanoparticle exposure (C) Improved intracellular ROS production in Ag-NPs -treated cells. $(\mathrm{N}=3)$ and ${ }^{* *} \mathrm{P}<0.001$. 

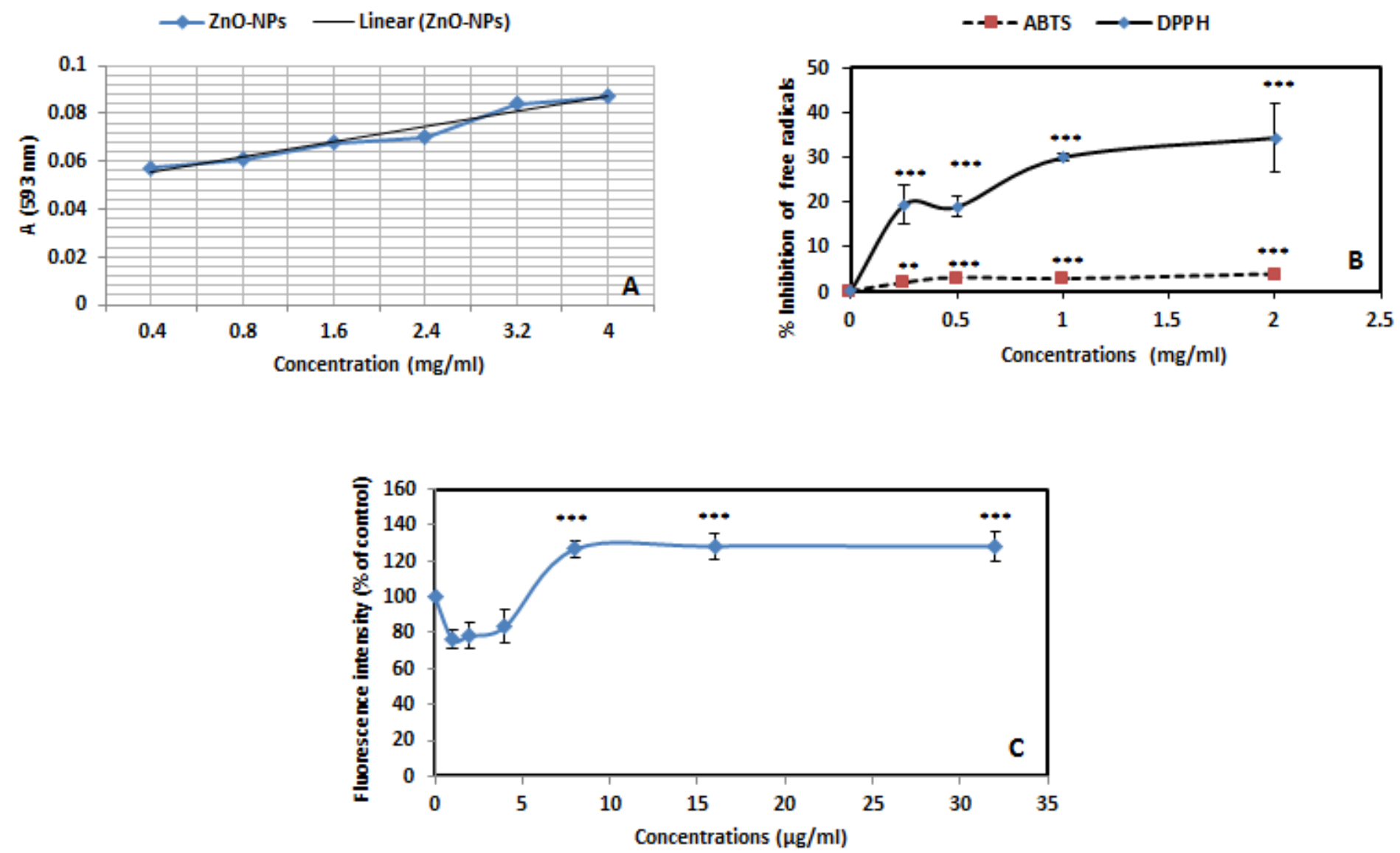

Figure 6

The ZnO-NPs antioxidant properties. (A) Ferric Reducing Antioxidant Power (FRAP) of the ZnO-NPs. (B) Scavenging of ABTS and DPPH free radicals with ZnO-NPs exposure (C) Enhanced intracellular ROS production in ZnO-NPs-treated cells. $(\mathrm{N}=3)$ and $* \star * \mathrm{P}<0.001$. 

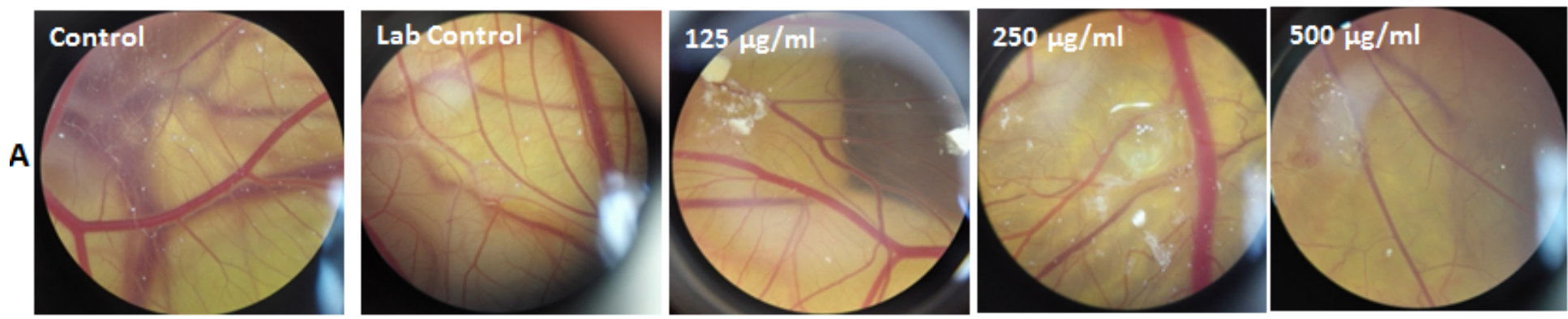

\begin{tabular}{|ccccccccc|}
\hline Groups & $\begin{array}{c}\text { Mean of Number } \\
\text { of blood vessels } \\
\pm \text { SD }\end{array}$ & $\mathrm{p}$-Value & $\begin{array}{c}\text { Mean of length } \\
\text { of blood vessel } \\
\text { (mm) } \pm \text { SD }\end{array}$ & $p$-Value & $\begin{array}{c}\text { Mean of length } \\
\text { of embryo }(\mathrm{mm}) \\
\pm \text { SD }\end{array}$ & $\begin{array}{c}\mathrm{p} \text {-Value } \\
\text { Mean of weight } \\
\text { of embryo(mg) } \\
\pm \text { SD }\end{array}$ & $\mathrm{p}$-Value \\
\hline Control & $31.17 \pm 1.1$ & - & $37.13 \pm 1.6$ & - & $37.5 \pm 1.1$ & - & $2.97 \pm 0.23$ & \\
\hline Lab C & $30.73 \pm 2.28$ & $\mathrm{p}>0.05$ & $36.54 \pm 1.5$ & $\mathrm{p}>0.05$ & $37.26 \pm 1.5$ & $\mathrm{p}>0.05$ & $2.94 \pm 0.33$ & $\mathrm{p}>0.05$ \\
\hline $125 \mu \mathrm{g} / \mathrm{ml}$ & $31.08 \pm 2.75$ & $\mathrm{p}>0.05$ & $37.09 \pm 1.3$ & $\mathrm{p}>0.05$ & $37.76 \pm 0.4$ & $\mathrm{p}>0.05$ & $2.93 \pm 0.36$ & $\mathrm{p}>0.05$ \\
\hline $250 \mu \mathrm{g} / \mathrm{ml}$ & $27.75 \pm 1.3$ & $\mathrm{P}<0.05$ & $32.44 \pm 2.6$ & $\mathrm{P}<0.01$ & $36.43 \pm 0.6$ & $\mathrm{p}>0.05$ & $2.67 \pm 0.16$ & $\mathrm{p}>0.05$ \\
\hline $500 \mu \mathrm{g} / \mathrm{ml}$ & $22.62 \pm 2.5$ & $\mathrm{P}<0.001$ & $27.77 \pm 3.0$ & $\mathrm{P}<0.001$ & $35.92 \pm 1.0$ & $\mathrm{P}<0.05$ & $2.5 \pm 0.31$ & $\mathrm{P}<0.05$ \\
\hline
\end{tabular}

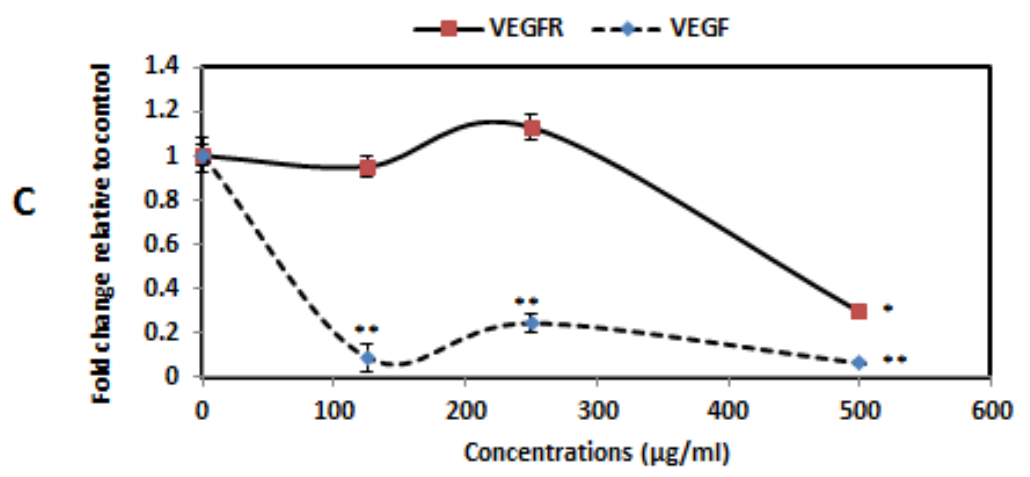

Figure 7

CAM assay (A) The stereomicroscopic micrograph of CAM following the treatment with different doses of Ag-NPs, (B) Decrease in mean number and length of blood vessels and also changes in fetal growth factors (height and weight) following the treatment with different doses of Ag-NPs $(N=8) ;\left({ }^{\star} P<0.05\right.$, $\left.{ }^{*} P<0.01,{ }^{*} * *<<0.001\right)$. (C) Change in VEGF and VEGF-R gene expression in Ag-NPs-treated samples compared to control. Data are significant at the level of ${ }^{*} \mathrm{P}<0.05$ and ${ }^{\star *} * \mathrm{P}<0.001(\mathrm{~N}=3)$. 

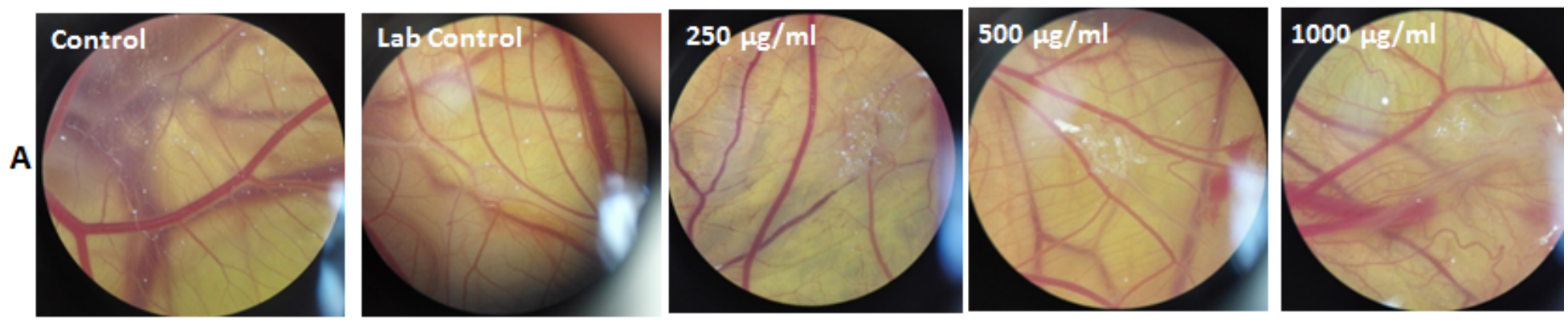

\begin{tabular}{|c|c|c|c|c|c|c|c|c|}
\hline Groups & $\begin{array}{c}\text { Mean of Number } \\
\text { of blood vessels } \\
\pm \text { SD }\end{array}$ & p-Value & $\begin{array}{l}\text { Mean of length of } \\
\text { blood vessel } \\
(\mathrm{mm}) \pm \mathrm{SD}\end{array}$ & p-Value & $\begin{array}{c}\text { Mean of length } \\
\text { of embryo (mm) } \\
\pm \text { SD }\end{array}$ & p-Value & $\begin{array}{c}\text { Mean of weight } \\
\text { of embryo(mg) } \\
\pm \text { SD }\end{array}$ & p-Value \\
\hline Control & $31.17 \pm 1.1$ & - & $37.13 \pm 1.6$ & - & $37.5 \pm 1.1$ & - & $2.97 \pm 0.23$ & \\
\hline Lab C & $30.73 \pm 2.28$ & $p>0.05$ & $36.54 \pm 1.5$ & $p>0.05$ & $37.26 \pm 1.5$ & $p>0.05$ & $2.94 \pm 0.33$ & $p>0.05$ \\
\hline $250 \mu \mathrm{g} / \mathrm{ml}$ & $30.53 \pm 2.76$ & $p>0.05$ & $35.59 \pm 2.6$ & $p>0.05$ & $37.66 \pm 0.7$ & $p>0.05$ & $2.72 \pm 0.3$ & $p>0.05$ \\
\hline $500 \mu \mathrm{g} / \mathrm{ml}$ & $35 \pm 2.8$ & $P<0.05$ & $38.22 \pm 1.8$ & $p>0.05$ & $38.29 \pm 0.9$ & $p>0.05$ & $3.28 \pm 0.23$ & $p>0.05$ \\
\hline $1000 \mu \mathrm{g} / \mathrm{ml}$ & $36.62 \pm 2.48$ & $P<0.01$ & $42.48 \pm 2.09$ & $\mathrm{P}<0.01$ & $40.78 \pm 2.2$ & $P<0.01$ & $3.44 \pm 0.4$ & $\mathrm{P}<0.05$ \\
\hline
\end{tabular}

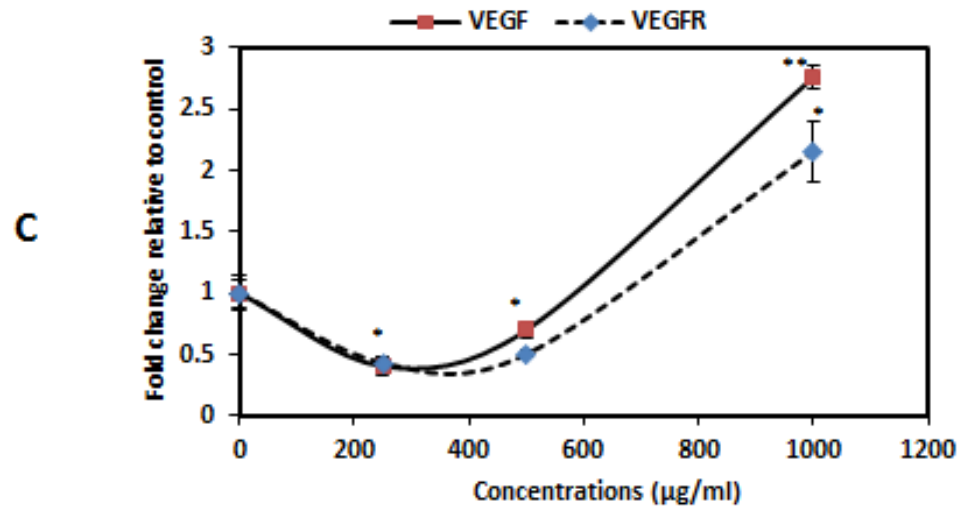

\section{Figure 8}

CAM assay (A) The stereomicroscopic micrograph of CAM following the treatment with different doses of ZnO-NPs, (B) Change in mean number and length of blood vessels and embryonic growth factors in ZnONPs treatment $(N=8) ;\left({ }^{*} P<0.05,{ }^{*} P<0.01,{ }^{*} * *<0.001\right)$. (C) Change in VEGF and VEGF-R gene expression in ZnO-NPs-treated samples compared to control. ${ }^{*} \mathrm{P}<0.05$ and ${ }^{* * P}<0.01(\mathrm{~N}=3)$. 